\title{
Reconciliation through Church Union in post-Apartheid South Africa: The Uniting Presbyterian Church in Southern Africa
}

G A Duncan

(University of Pretoria)

\section{ABSTRACT}

Reconciliation through Church Union in post-Apartheid South Africa: The Uniting Presbyterian Church in Southern Africa

This paper will argue that the union which brought the Uniting Presbyterian Church in Southern Africa into being was based on an inadequate view of reconciliation in a Christian context. While lip service may have been paid to the authentic concept, flawed views have led to many misunderstandings concerning the mission and vision of the new church, and despite attempts at reformation and renewal, reconciliation as justice restored still evades the ethos of the young denomination.

\section{THE CONTEXT}

The context which provides the backdrop for this paper is well described by Schreiter (1992:15-16):

"South Africa presents another kind of situation, where the different Christian churches have found themselves on both sides of the apartheid question, but where many of the churches have taken active roles in the struggle against apartheid. Here certain laws have been taken away, but it is still uncertain about what will take their place. Moreover, racism will continue to function despite new legislation”.

A little earlier it was written:

"Traditionally South African society has been very divided between different groups of people. This means that present divisions run deep in the social history of the country. These divisions have almost invariably been justified or explained by religious claims and commitments, a phenomenon which remains true today.... All the religious groupings in South Africa and especially Christians are often radically divided in their perception and analysis of the social situation.... At the center of inter-group conflict is the perception by 
groups that they are being unjustly treated. While such a perception may be wrong or distorted, that does not make the sense of being wrongfully treated any lass real for those involved" (HSRC 1988:1415).

Written several years before the coming of democracy, the general point is still true as is confirmed by Khabela (2000:7) concerning the church as an agent in society: 'since the church does not operate in a political vacuum, there is always an underlying social-political context'. All of this testifies to a tremendous need for reconciliation in both church and society.

\section{THE MEANING OF RECONCILIATION}

Reconciliation takes place in the context of the mission of the Church and may be defined as human participation in God's work of reconciling the entire created order to Godself. De Gruchy (2002:2) focuses on reconciliation as 'restorative justice' both in the 'renewal of interpersonal relations, or the transformation of society', that is healing damaged or ruptured relationships. Reconciliation is an attitude rather than an acquired skill. De Gruchy (2002:26-27) is correct when he says that the theological import of reconciliation is jettisoned in that it is viewed mainly in a secular sense which does not require God, i.e. it is purely inter-personal between human beings, groups or in the political realm. It also has a historical perspective in that it refers to the outworking of past hurts that alienate, i.e. it requires an understanding of social history (see De Gruchy 2002:189). But it also relates to the future, moving from 'exclusion to embrace' (Volf 1996). Our work of reconciliation must be based in a conviction that:

"supported by a Christian faith which believes in God's option for the oppressed and violated and God's compassion and love for life, I cannot but express a vision for the present transformed into the future. The transformation from what is today considered power (often identical with coercive, oppressive, destructive power) to a power that is life affirming, and life enhancing, often points to the masking of unequal power relationships. Poor and rich always represent an irreconcilable contradiction, as does diversity based on oppression and lack of care. But black and white, men and women, old and young, represent a potentially reconcilable diversity.... The 
great rift is between care and carelessness, justice and injustice, mercy and mercilessness, compassion and indifference.... What divides is not difference, but sin, oppression and injustice" (Zaru 2000:10)

The entire practice of reconciliation involves forgiveness which involves the sacrifice of the right to justice in terms of revenge and restitution. There needs to be some avenue for both sides to experience forgiveness and repentance as a prelude to experiencing the mutuality of reconciliation. This is made possible by God's prior action:

"When we were God's enemies, we were reconciled to him through the death of his Son, how much more, now that we have been reconciled, shall we be saved by his life! But that is not all: we also exult in God through our Lord Jesus Christ, through whom we have now been granted reconciliation” (Rm 5:10-11, Revised English Bible).

That reconciliation has already been enacted and we need to appropriate it:

"We who have been embraced by the outstretched arms of the crucified God open our arms even for the enemies - to make space in ourselves for them and invite them in - so that together we may rejoice in the eternal embrace of the triune God" (Volf 1996:131).

While reconciliation is God's work, we are impelled to be active participants:

"All this has been the work of God. He has reconciled us to himself through Christ, and has enlisted us in this ministry of reconciliation: God was in Christ reconciling the world to himself, no longer holding people's misdeeds against them, and has entrusted us with the message of reconciliation. We are therefore Christ's ambassadors. It is as if God were appealing to you through us: we implore you in Christ's name, be reconciled to God!” (2 Cor 5:1820).

Our growth towards complete and authentic humanity would then be dependent on our acceptance (in Tillichian terms) of one another. This might seem to be rather too simplistic and underestimate the degree of suffering which has been experienced and the damage done by 
proceeding to a solution which tidies up the lose ends of unexpressed emotions, unhealed wounds and ineradicable memories without considering the ongoing inability to forget beyond forgiveness ie. it involves moral transformation. Clearly then, in terms of church union, the process does not end with the act of consummation but is an ongoing process, especially as in this case study, the politics of cultural identity are active and constitute a critical factor in the process.

But we cannot forget that reconciliation is related to God's covenant with creation which is:

"a gracious commitment on the part of God to heal and restore God's relationship with the world so that it might be brought to perfection .... Covenant implies a new commitment to one another that transcends simply agreeing to co-exist, with hostility continuing to simmer beneath the surface and periodically breaking out in another round of violence” (De Gruchy 2002: 185).

Within the context of the South African system we have to take account of the role of racism as the most important determinant in the process of reconciliation. Mpako (1999:236-237) offers a compelling comment:

"Racism is the internalized belief in the superiority of the white race over the black race - with the result that the culture, norms, theories and practices of the dominant white racial group come to be seen and treated as normative for all ... [it] continues to be an important issue because there is a (most probably unconscious) racist dimension to our present self-definitions. It is therefore important to realize that in talking about racism the point is not whether people consciously or deliberately decide to act in 'racist' ways or not. Rather the point is in what ways racism has, through social conditioning, embedded itself in our psyche and continues to shape and to influence our lives in the present. While people may be right in denying that they are 'racist' in the former sense, they are usually wrong when they deny being 'racist' in the latter sense. Racism is therefore most appropriately considered a sickness that affects us or a demon that possesses us, although unconsciously for the most part”.

This theoretical statement is demonstrated in practice through assuming white ways are better, use of differing standards, stereotyping black 
people, dysfunctional rescuing, blaming the victims, denial of difference and denial of the psychological significance of difference. All of these are manifested in the church context and hinder the process of reconciliation by denying a need for it.

\subsection{What reconciliation is not}

Reconciliation has a history of varied meanings such as bringing peace, restoration to favour, reaching agreement or consensus. In the secular context reconciliation has other related meanings which are also relevant to this purpose. However, they are aberrations from the Christian meaning of reconciliation. It can mean the restoration of friendly relations between those who have been separated. This can be done in such a way as to minimalise the sufferings experienced, and thus trivialize human identity and dignity. Consequently it cannot be done hastily. It can be a demonstration of compatibility of those who appear to be incompatible and it can also imply appeasement or acceptance of something which is disagreeable. However, it is not conflict mediation where parties have legitimate concerns which are incompatible, resulting in some kind of trade off which produces an uneasy peace which can flare up occasionally since values cannot be easily managed. And it can indicate the act or process of making changes to improve some situation. It is not liberation which must be prior to reconciliation. It is also not consensus as there are some things which are non-negotiable. Conflict and its roots must be exposed and dealt with. Enmity between God and his created order (Ja 4:4) is not a permanent state of affairs. However, these secular definitions are often taken as a substitute for a theological approach for reconciliation as can be seen from a particular context which has provided a significant opportunity for reconciliation.

\section{THE CASE OF THE UNITING PRESBYTERIAN CHURCH IN SOUTHERN AFRICA}

\subsection{History}

The Scottish branch of Southern African Presbyterianism has its origins in the early years of the nineteenth century in Cape Town. From its inception it came as a divided body. In 1882 a Federal Council was formed to attempt to unite the disparate 'colonial' congregations and presbyteries which had been established since 1812. Together with the 
United Presbyterian Church of Scotland (UPC) missions they came in 1897 to form the white dominated Presbyterian Church of South Africa (PCSA) espousing the ideal of a church embracing different races. In 1898, the Free Church of Scotland (FCS) mission suffered a serious setback as a result of the Mzimba Secession which had its roots inter alia in a desire to form an autonomous church arising out of a context of white domination and racism. In the long-term (see Duncan 1994) this led to the formation of the black Bantu Presbyterian Church of South Africa (BPCSA, renamed the Reformed Presbyterian Church in Southern Africa in 1979) in 1923, an autonomous black church 'albeit with a strong presence and guidance of the Church of Scotland' i.e. a number of Scottish missionaries (Khabela 2000:9). For some time relations were maintained through mutual representation at General Assembly level. All the while both denominations cherished the ideal of a united church.

In 1934, a type of comity arrangement was made which was to become a serious source of dissension. The agreement stated that the PCSA would be responsible for work in urban areas which meant the BPCSA members would become members of the PCSA while they were migrant labourers, and that the BPCSA would restrict its work to rural areas. But when white members of the PCSA moved from the cities to take over whatever positions in the rural areas, the rule will not apply. Only the BPC will have no right to form congregations in the cities. What was significant is that many of the ministers involved were retired missionaries who transferred their allegiance to the PCSA on retirement.

Xapile (1994:58) is certainly correct in his assessment that church unity: 'cannot be discussed in isolation from the experience of those involved'. The political situation dominated by racism certainly was a major contributing factor in the failure of unity negotiations. Following this, both denominations continued to develop local relationships with the support of both General Assemblies. It has to be noted that at various times, both denominations had been involved in union negotiations with the United Congregational Church in Southern Africa (UCCSA) and the Evangelical Presbyterian Church in Southern Africa (EPCSA) but that these have failed for similar reasons. In 1990, 'the Assemblies acknowledged the past failures in relationships and 
committed the Churches to working towards better relationships through increased contact and cooperation' (PCSA-RPCSA Union Committee, General Assembly Report,1998).

It was a change in this same political context that was a catalyst for unity talks to be resumed: 'In the spirit of national euphoria which surrounded the first democratic elections in South Africa in 1994, the Reformed Presbyterian Church initiated union discussions with the Presbyterian Church' (Duncan 2003:359). The history that had maintained separation now encouraged reconciliation. One of the secular motivations which embarrassed the RPCSA into action was articulated by its Moderator when he 'challenged the Assembly to consider whether the Church had not been overtaken by a secular society in its willingness to forgive past wrongs and to build a united nation' (File RPCSA:GA, PCSA:GA, RPCSA/PCSA Ecumenical Relations Committees [ERC], 15/7/94:2). Three points were agreed at the initial meeting - negotiations regarding church structures had to be concurrent with building trust, and a sense of urgency was expressed. Towards this end an optimistic timetable was drawn up. This was only to be amended once to allow union to be consummated in 1999 rather than at an earlier date.

The Central Committee, set up to prepare the way for union had operated by means of task forces and sub-committees to examine relevant areas of work in the two denominations. The 1995 General Assemblies agreed in principle on union and the Central Committee was instructed to prepare a plan of union. Along with this and the work of the committees, a Basis of Union was drawn up which was based on that first prepared in 1970 in anticipation of union between the PCSA, RPCSA and EPCSA. The position of the UCCSA also had to be considered in the light of united congregations and the history of union attempts involving it.

\section{Early commitment}

The second meeting of the Central Committee (File SCU, 23/11/94) emphasised the need to make a clear commitment to union to avoid time being wasted later if one or both denominations withdrew, and to critically analyse historical issues which might impede the process of union. A scheme was devised to involve membership at all levels. A 
new positive attitude was demonstrated in that mutual representa-tion was sought in courts (councils), worship services and meetings of both denominations and concern was expressed when this did not take place. It was, however, assumed at this early stage that the com-position of General Assembly would reflect that of the PCSA for the sake of 'effectiveness' though what this meant was not specified.

\section{Manual}

It was at an early meeting in 1995 that the RPCSA delegation raised the possibility of adopting the PCSA Manual since it was more up to date (File SCU, Min.PR38.6 ERC 6/6/95). This was later affirmed on the 19-10/3/96. However, this became a prime issue following union as was the case in Amatola Presbytery (see below):

"During the union negotiations the RPCSA delegates proposed in good faith that the PCSA Manual be used after the union as the Interim Manual; however it became a weapon of domination, in the view of some, because of their lack of knowledge and experience of it... Meanwhile the Executive Committee pleads for sensitivity in the application of the Manual by the Presbytery, especially where issues of culture or custom are concerned" (File SCU, Min. Interviews 7, ExCom, SCU, 21 July 2000).

This was difficult due to different perceptions of the function of the manual and the manner it was applied, even racially:

"The legal framework does not help us because it requires one group to change, and it leaves the other group in a comfort zone where they are not required to change. The acid test of a loving relationship is the willingness of married partners to change and adjust for the sake of one another, because they love one another" (File SCU, Statement by Concerned Members [of the Presbytery of Amatola] to the ExCom of the SCU, East London, 23 July 2000:2).

For many in the RPCSA the agreement to use the PCSA Manual came to be perceived as 'a psychological way of preparing us for absorption into the PCSA' (File SCU, Min PR160.k, UNCC, 9/6/98).

The pastoral nature of church discipline was often overlooked, especially with regard to ministers experiencing marriage difficulties. This would lead to substantial changes being implemented relating to 
ministerial marriage and divorce following union. A grave concern was that white ministers were treated more leniently than black ministers in the application of the Manual.

\section{Structures}

As has been noted above there was an early tendency to assume that structures of the PCSA would become normative for the uniting church, eg. in terms of committee membership. This was continued in the matter of evangelists where it was noted: 'they may be able to fit into one of the new categories in the PCSA's Church Growth Plan' (File SCU, Min. PR 84 corrected in Min. PR94, UNCC, 29/10/96). It is clear that the PCSA was continuing to formulate plans despite being involved in union negotiations. Yet, in the discussion on the term of office of elders great lengths were gone to in order to avoid potential conflict:

It was noted that:

- the Central Committee had previously agreed that it was desirable that no major changes be made in either Church in the period immediately before union, but that this could not be made binding on the General Assemblies; and

- that these and other changes which were to have been discussed at the 1996 PCSA General Assembly touched on sensitive areas which could complicate or compromise union negotiations (File SCU, Min. PR96, UNCC, 29/10/ 96).

\section{Property}

There was also an early assumption that immovable properties (i.e. land and buildings) would be held in the same manner as prior to union, ie. RPCSA properties would be vested in the trustees of the new denomination as would those of the PCSA whose title deeds were held by the General Assembly and properties acquired following union. However:

- congregations that presently owned their own properties should not be forced to transfer these to the Uniting Church as it was possible that the rights given to PCSA congregations by their constitutions would have to be carried over into the new church (File SCU, Min. PR96.(a)(i)(j). UNCC 29/10/96). 
- fixed property formerly held by other courts and congregations of the PCSA shall become the property of the corresponding bodies of the Uniting Church (Personal papers, Basis of Union 9.(b)).

The issue of land, already an extremely sensitive issue, was to be bypassed in a similar manner. The Business Committee of the RPCSA registered its concern that it was 'unfair in expecting only the RPC to register all its property in the name of the General Assembly of the Uniting Church when the PCSA was not required to do the same' (File SCU, Min PR126.b.iv, UNCC, 6/5/97). This situation had arisen as the result of the Group Areas Act and had caused the PCSA to give congregations involved their own constitutions:

"which gave them legal rights and status which they had never had before. This constitution gave congregations the right to leave the PCSA with their property, provided they went through a lengthy process involving consultation with the Presbytery .... the Assembly [subsequently] approved a new version of the Consti-tution without the severance clause, but had to rely on persuasion, because it could not force congregations to adopt the new constitution” (File SCU, Min PR 135.e, UNCC, 18/11/97).

This provided a mechanism for congregations which were not prepared to enter a union to leave. The same apartheid legislation had posed a problem for the RPCSA as the Church of Scotland had had to retain ownership of black occupied properties, but these transfers were virtually complete by this time. However the very fact that union was in process post-1994 indicates that the situation had altered radically and required new legislation. As it was, since most of the property whose title deeds were in the hands of individual congregations were white congregations, this was seen as a potential escape route for those congregations which might wish to withdraw from this union which brought a majority black church into being. The General Assembly of the PCSA had, however, in 1996 determined that all new registrations of fixed property should be in the name of the denomination. A number of congregations refused to sign the new constitution while even more ignored the request of the General Assembly. This issue, had it been taken up and dealt with could have provided a rallying point of commitment for the union and may have resolved some issues which have impeded the process of union. 


\section{Ministry}

In terms of ministry, there were clear differences on part-time/selfsupporting ministry, ministerial divorce and payment of stipend (Basis of Union, 8). In time, these would become contentious matters. But trouble erupted at the uniting Assembly:

"The closing General Assembly of the PCSA subverted the proposals of the Special Commission by discussing a document and bringing proposals which was prepared for the Assembly of the UPCSA, not the PCSA ie. they remained and voted as the PCSA" (Personal papers, State of the Union SA [2000]:1).

This happened because changes were being proposed to the PCSA process of selection and training of ministers. It led to an impasse in the Assembly that threatened the nascent unity of the brand new denomination. This was unfortunate since '.... [g]iven the complex situation of our histories, this can make ministry difficult. We are relatively young democracies and have the Apartheid and colonial legacies with us' (Masango 2000:5). Ministry was, therefore, a critical issue in the union.

\section{General Assembly Office}

For the first time an issue which would become problematic raised its head - the location of the General Assembly office (Min.PR20 (b) ERC 23/11/94). This became one of the most contentious issues of the union causing 'heated debate' (File SCU, Min PR126.b.iii, UNCC, 6/5/97) for among other reasons that after a number of concessions were agreed by the RPCSA (see below), this matter became a focus for the expression of serious discontent with the process towards union. The Basis of Union (7) stated: 'The office of the General Assembly of the Uniting Church shall be situated in a new (emphasis mine) venue, to be determined by the Special Commission, until such time as the Assembly may move it elsewhere'. At the time of writing (January 2005) this clause has not been honoured: The committee charged with this task has 'constantly procrastinated and subverted attempts to bring this issue to resolution' (Personal papers, State of the Union sa [2000]:1). The decision to base the office for a period of two years following union (File SCU, Min 21, Special Commission on Union [SCU], 10/2/99) gave the staff of the PCSA a clear advantage over the 
RPCSA staff who were based in the RPCSA Head Office in Umtata. In the event all PCSA staff who applied for posts in the UPCSA were appointed (File SCU, Min. A, ExCom, SCU, 7/6/99). A late application was received at this time from one RPCSA office staff member. However, the applicant was considered unsuitable for the post applied for though it was agreed that:

"it would be helpful to find a member of the RPCSA to fill at least one of the remaining positions" (Chief Accountant, Secretary to the Ministry Secretary and Driver) (File SCU, Min.A, ExCom, SCU, 7/6/99).

\section{Communication}

A decision to keep associations informed of progress through the official channels of the denominations (File SCU, Min PR 82, Union Negotiations Central Committee [UNCC], 19-20/3/96) rather than from the Negotiations Committee directly may have been unfortunate in the light of difficulties that would emerge later (cf. File SCU, Min PR 96.n, UNCC 29/10/96). Throughout the process towards union there was a concern:

"that information needed to be given to members of the Churches about the union negotiations and the proposals for union, because it seemed that in many cases ministers were not passing on the information that had come to them. It might therefore be necessary to appoint people to visit the presbyteries" (File SCU, Min PR115.13, UNCC, 19/2/97).

The issue of communication was dealt with later and presbyteries were charged with this responsibility (File SCU, Min PR116, UNCC, 19/2/97). Following the subsequent General Assemblies, there was still a feeling 'that the information was not getting through' (File SCU, Min PR137, UNCC, 18/11/97). This matter was kept before the committee and its successor, the Special Commission on Union and has subsequently been cited by various groups on occasion as a reason for difficulties within the union.

\section{Fears}

But there were other matters of communication that surfaced during negotiations. These were described as 


\section{Emotional Problems:}

"It was observed, for example, that on the part of the RPC there was a fear that the proposed union may lead to their domination by the predominantly white PCSA. On the other hand, the white members of the PCSA were coming into the union with the feeling that, as a result of the introduction of the new political set-up, they have lost everything” (File SCU, Min PR 127.3.a, UNCC 6/5/97).

The RPCSA concern was a longstanding concern that always surfaced in union talks. The PCSA worry focussed on an external concern which reflects a view of the Church as a place of safety and security from change and anxiety. Hendricks (1999:334) has drawn the paradoxical conclusion that the Church 'is the last stronghold where the "old ways" could be preserved. Others are of the opinion that it should be the first place to transform'. This would broadly describe the PCSA and RPCSA attitudes to union. Nonetheless account was taken of the fact 'that racial divisions were still very much a feature of the church, as of society, that it was the church's calling to break these down, but it was clear that this would take time' (File SCU, Min. PR137, UNCC, 18/11/97). However, the PCSA Centenary Congress (1997) had taken account of part of its past history:

"the PCSA needed to repent of the way it had treated the UCCSA ${ }^{1}$ in union negotiations with that Church, apparently with the idea that the same should not happen again in the present negotiations”.

\section{Associations}

Although the merger of associations had been discussed frequently, by July 1999, two months before union, only the mens'associations had made any progress towards union though both the womens' and mens' associations had initiated union talks on their own. The Special Commission later apologized to the General Assembly for failing to initiate the union of the church associations.

In the meantime, a serious problem arose within the bounds of the Presbytery of Amatola concerning the union of the womens' or-

1 The UCCSA had been deeply hurt by the PCSA's withdrawal from union negotiations with them in the 1980s. 
ganizations. This related to the role of ministers' wives in the respective former denominations. This matter quickly escalated into a denominational concern focused on the issue of racism and cultural difference. The Executive Committee of the SCU misunderstood the root of the matter: 'a tendency to turn local issues into denominatio-nal problems ... which unnecessarily undermines the union' (File SCU, Min. Interviews 5, ExCom, SCU, 21 July 2000) [see below]. The issues were indeed local but they were occurring throughout the new denomination though in a less spectacular manner than in Amatola:

"We know that there is a sizeable number of ministers, elders, and members of the former RPCSA outside the bounds of the Presbytery of Amatola who are equally concerned about the state of the union" (Personal papers, Statement to the ExCom of the SCU, East London, 23 July 2000:1).

The problem with the womens' union was cited by the SCU as 'general dissatisfaction with the union' (File SCU, Min. SCU, 21 November 2000). The Womens' Christian Association (WCA) of the RPCSA claimed that they had not been adequately consulted during the period leading to union. While procedures had been put in place for consultation, clearly these failed as can be seen in the section on Communication above (see File SCU, Min. 2 (b), SCU, 10 February 2001). Further, the WCA in the RPCSA had a different relationship with its General Assembly than the Womens' Association (WA) of the PCSA. In practice, it had its own general meeting and was more independent though it remained under the authority of the General Assembly. It also had difficulty understanding the urgency for union when the WA of the PCSA functioned as two movements, uniformed (black) and non-uniformed (white). Relating to difficulties with the union of the womens' organisations, the WCA of the RPCSA was treated with a degree of contempt:

"We find it difficult to sit comfortable in a body that seems to treat the WCA [mothers of the Church] as some confused organisation that does not know what it is doing. Those who are African will know that an insult on your mother goes much deeper than an insult on one's self. It should therefore not appear strange that the issue of the poor treatment of the WCA in our Presbytery became the break point for us” (Personal papers, Concerned Group Statement 2000:5). 
Problems arose between other associations in the process of coming together. The Youth Fellowships operated under different structures and issues of uniform and age restrictions emerged. Serious difficulties regarding the proposed 'Articles of Association' led to a dead-lock' for a time. The mens' organizations also suffered from dissension relating to uniform at a later stage and this has threatened their unity.

The role of the Presbyterian Black Leadership Consultation (PBLC) of the PCSA was problematic in two senses. First, it had no counterpart in the RPCSA (which was a black church and needed no such organisation) and second, because its constitution had been regularly rejected within the PCSA 'because of the clause that restricted membership to Black people' (File SCU, Min. ExCom, SCU, 20 February 2002) and consequently gave white people no power over it, except perhaps through allocating its annual budget.

\section{Presbytery problems}

While some regarded the problem in Amatola Presbytery as a local one, local to the womens' associations or local to one presbytery, many within the bounds of that presbytery believed that there were outstanding issues related to the principles on which the union was based (see Personal papers, Concerned Group Statement). With particular regard to Amatola, it declared 'some members of Presbytery believe that there is an uneasy peace at the moment rather than a genuine reconciliation' (File UPCSA:GA, UPCSA Supplementary Papers, General Assembly, 2004:378). And even the Special Commission on Union admitted that 'there have been tensions in some presbyteries'. There were also problems in Central Cape Presbytery, but it was in Umtata Presbytery that a particularly severe problem arose.

This had its origin in a dispute which arose between two ministers and their Sessions which occurred prior to union and which was never satisfactorily resolved though a false reconciliation had been effected in order to prevent both ministers from being appointed to congregations outside the presbytery. This became a prolonged dispute between two ministers and the Presbytery of Umtata. As a result both ministers resigned and withdrew with their congregations to reconstitute the RPCSA. Legal proceedings were instituted against them by the Church 
to evict them from the manses they occupied and the church buildings. This was cited as problem arising out of the union which was only true in part. Legal proceedings were suspended early in 2004 on the initiative of the newly appointed General Secretary and then subsequent General Assembly sanctioned an attempt at reconciliation.

\section{Racism}

Throughout the denomination, there was a perception among white members that racism was not an issue ${ }^{2}$ (cf. Duncan 2003:363). Yet, it was an issue for it had merited a section in the first draft of a statement on the mission of the Uniting Church (Germiquet \& Khabela 1998):

"In the coming together of previously divided people and churches, past misunderstandings, hurts and conflicts need to be faced and resolved. There will be a need for members to have the freedom to say what they think and believe as well as having the freedom to accept criticism. Criticism, when received should be examined and analysed. There is no reconciliation without an acknowledgement of error, but true confession, which needs to be met with forgiveness, opens the way to reconciliation”.

While racism was not specifically mentioned, this was the major factor that divided people.

However, the problem was nor simply the problem of one presbytery. 'The problem existed in embryo during negotiations towards union. It was manifested in numerous examples of superiority, which are traceable to racial arrogance' (Personal papers, State of the Union sa:1). In addition, other presbyteries were 'experiencing similar tensions which ...have been expressed differently e.g. [non or] irregular attendance at and/or non-participation in meetings' (Personal papers, State of the Union sa:2). What made Amatola significant was that the new presbytery was an amalgamation of two strong presbyteries of the former denominations, the one totally black and the other white

2 This is possibly related to the general unwillingness to recognise and admit to the existence of racism in the post-1994 period (see Min. 2 (b), SCU, 10 February 2001) - "there was 'still a lot of racism in the country as a whole and in the Church"”. 
dominated. This meant that different value systems were in operation. One of the conclusions of the ExCom of the SCU was that:

“'baggage' carried over from the old Presbyteries has contributed to distrust and division, eg. incidents of fraud and black-white divisions in the [former] King William's Town Presbytery and memories on the part of former RPC members of ill-treatment by whites in the past” (File SCU, Min. Interviews 6, Ex Com, SCU, 21 July 2000).

The nature of the baggage is not defined but obviously relates to the issue of racism (i.e. 'black-white divisions'). There was a common understanding on the part of former PCSA members that in the UPCSA, many aspects of the PCSA would simply be continued, eg. in the method of administration of Amatola Presbytery and payment of ministers (the former Ciskei Presbytery had its own method of paying annual bonuses to ministers, sanctioned by the law of that denomination, involving what was interpreted by PCSA ministers as misappropriation of church funds), without such matters ever being discussed by the Presbytery. But the problem had both a structural (as has been demonstrated) and relationship aspect:

"What we are experiencing is that there is no meaningful contact between the black and white congregations.... Instead of being joyful in the union we see ourselves battling all the time with undermining and a sense of superiority from our brothers and sisters who make us feel that everything done by the RPCSA in the past is sub-standard or questionable....

Racism is tearing our nation apart. It will tear this union apart unless we face it and address it. Some of us have spent all our adult life struggling against racism in society and we do not see ourselves having any role in a Church that sits comfortably with racist practices....We see no visible attempts to tackle this wall of separation with urgency and commitment" (Personal papers, Concerned Group Statement 2000:6).

This was true in fact. The Uniting Presbyterian Church is 'a church that operates within two cultures namely Western and African cultures' (Masango 2000:5).

But, more than that: 
"The tale of the two denominations was itself very much the tale of two nations, a tale of inequalities, a tale of racial division, a sad tale of what centuries of racism and decades of apartheid had bequeathed to the people of our land. To paraphrase Thabo Mbeki in his much condemned Two Nations Speech, we looked at ourselves and we saw two churches: one of these churches was white, relatively prosperous, regardless of gender or geographic dispersal. It had access to a developed economic power, education, infrastructure etc........ The second was black and poor, with the worst affected being women in rural areas and rural communities in general; characterised by deprivation and under-development and want ...But that was not all. Each one of our two denominations carried a huge baggage of issues, of undermining, of betrayal, and of open hostilities at times" (Personal papers, Finca The vision and agenda of union: A church healed for the healing of a wounded nation, paper delivered at Mission Imbizo, 25 November 2004, Benoni, emphasis in original) .

This demonstrates the lack of attention given to matters of reconciliation in the first five years of the union.

But there was no need for this to hamper the development of racial unity. The matter was next officially raised in the Moderator's Address in 2003:

"Racism is an inherent spiritual problem rooted deep in lifes [sic] and experience .... What needs to be realised is that racism is not easily rooted out of the human psyche. For many, it is the result of a successfully inbred process. There is a need for a more focussed and well-organised effort which will practically transform the day-to-day reality of church life” (Duncan 2003:363 cf. Mpako 199:235-240).

Little heed was paid to the challenge made except that the next Moderator arranged for a workshop on racism to take place at the beginning of the 2004 General Assembly. The only problem was that this only touched the commissioners to that Assembly, around one hundred and twenty people and no further substantial action is contemplated. 


\section{Concerns about the union}

These problems were given classic expression within the already cited problems of Amatola Presbytery whose basic principle was encapsulated in a statement submitted to the SCU:

"We expect that we will be judged and condemned for not suffering silently and for raising in such a frank manner the uncomfortable matters we address in this statement. But we believe that it is part of our Christian responsibility to speak the truth in love, even when it hurts to do so. We believe that it is unChristian to pretend and say: Peace! Peace! Where there is no peace. We raise these matters with deep respect for the Church and with love for it. We would like union between the RPCSA and PCSA to be a fulfilling relationship of love for which we praise Christ; and not a loveless marriage which we will endure for the rest of our lives because we fear a public scandal of separation” (Personal papers, Concerned Group Statement 2000:1).

The Concerned Group believed that the Amatola incident with the WCA and WA was merely a symptom of a 'dysfunctional union' and a catalyst for reflection.

Negative attitudes towards union on the part of the PCSA were cited as a matter of concern: "There has been a demonstrable lack of respect for the traditions, institutions and views of the RPCSA' (Personal papers, State of the Union sa [2000]:1). There was also an awareness that members of the PCSA viewed the RPCSA as desiring union because it was in financial crisis, administrative chaos and its ministers were seeking to benefit from its wealthy pension fund. The RPCSA gave an assurance that it did want to benefit from that to which it had not contributed '[a]lthough it could have insisted that the mind of Christ in Acts 4:32 requires that we promote a spirit of sharing within the Body of Christ' (Personal papers, Concerned Group Statement 2000:2). The willingness to make concessions for the sake of union was also cited as a matter of concern (Personal papers, Concerned Group Statement 2000:3). Yet,

"[i]n the process of doing this we have unfortunately communicated what has been interpreted by some brothers and sisters in PCSA 
members as a sign that we were desperate to unite with the PCSA at all cost...” (Personal papers, Concerned Group Statement 2000:3).

This was related to the issue of relative poverty:

“... the RPCSA had dignity in its poverty... never begged for handouts but it lived out of the generous giving of the poorest of the poor who have been most loyal to the Church .... As a church whose members belonged to the discriminated and exploited black section of the South African community, it could not compete with the PCSA.... The RPCSA had a different wealth, which is not measured by investments and bank balances. It was a spiritual wealth that manifested itself in its dignity in worship, the service it rendered to the community, and the enormous respect it enjoyed in the ecumenical fellowship of churches and the eyes of the people" (Personal papers, Concerned Group Statement 2000:3).

I say relative poverty because the RPCSA did have substantial investments and assets to offset its bank overdraft, many of which have been realised and used to offset cash flow problems in the UPCSA without due acknowledgement as to their source. It is interesting that at no time was the socio-economic issue of how the PCSA became a wealthy church raised and interrogated.

The 'fear of absorption into PCSA structures and ways'; (File SCU, Min. PR136, UNCC, 18/11/97) was a constant theme that manifested itself. The WCA expressed this clearly: 'union with the PCSA is more of an absorption of the RPCSA then genuine union' (see File SCU, Min. 2 (b), SCU, 10 February 2001). The Concerned Group were explicit in their view of this matter:

"The identity, the culture, and the ways of doing things which the RPCSA members were used to and held dear, are disappearing. The PCSA, on the other hand, is remaining exactly as it was before September 1999. The RPCSA is being recreated into the image of the PCSA.... We request the Special Commission on Union to do a small exercise and list on a piece of paper things that have changed in the former PCSA and compare that list to things that have changed in the former RPCSA, and to answer the question honestly and truthfully of whether this union is not heavily biased in favour of the PCSA” (Personal papers, Concerned Group Statement 2000:3-4). 
As far as can be ascertained, little or no change took place in the PCSA while the following changes took place in the RPCSA which involved giving up its General Assembly office and personnel including having to accept non-ministerial office staff for the Presbyterian Employees' Pension Fund, the time of General Assembly, the composition of General Assembly, the method of the election of General Assembly Moderator, the attendance of the Womens' Annual Conference at General Assembly, its meetings procedure (voting vs. consensus, indaba sessions) and accepting the practice of allowing notices of motion to be made at General Assembly, the Manual of Law, Practice and Procedure, different types of congregations, geographically based committees, the method of collecting assessments, the method of paying stipends, the ownership of property, the system of selecting candidates for ministry, the representation of elders at Presbytery, the presence of associates at meetings excluding Sessions, accepting the possibility of electing an elder as General Assembly Moderator and the Order of Lay Preachers.

The lack of an attitude of wish for reconciliation was significant. The Concerned Group in Amatola Presbytery claimed:

"We desire union with the PCSA and we need it desperately. It is not only timely for us to move into a new century and into a transforming South Africa as a united body, but most importantly we believe that the Lord of the Church wants it to be united. But that union must be genuine union. Both partners must loose (sic) something very dear in order to embrace the new. This is not happening in this union" (Personal papers, Concerned Group Statement 2000:4).

There appeared to be little desire that a 'new creation' (2 Cor 5:17) should come into being despite the view of the Union Committee that:

"Unity is admittedly in the main a consciousness of our present, existential unity in Christ, but this does not deny the need for our social and religious structures to reflect our unity in Christ” (File UPCSA:GA, PCSA-RPCSA Union Committee, General Assem-bly Report, 1998).

However, in reality there was consequently, little sign of reconciliation brought about by being 'in Christ'. What appears to be the case was 
that both sides in unity talks had brought a defensive attitude to negotiations wanting to give up as little as possible in the uniting church. A more open and transparent approach of bringing and offering the best in each tradition with a committed desire to create a 'new being' would have made sacrifice far easier and would have caused far less stress.

Areas where each party had to accept change or where the status quo remained or that caused little conflict included presbytery boundaries, pension funds ${ }^{3}$

\section{The Skuilkloof Eleven}

As the result of an acknowledgement that things in the union were not progressing smoothly, a meeting was convened at Skuilkloof Retreat Centre consisting of groups of leaders from both former denominations on 11-12 March 2002 at the initiative of the Session of St Columba's, Parktown congregation. A management consultant, Tim Hough, facilitated the discussions. The precipitating factor was a financial crisis to which was added concerns about the management of the denomination. It was agreed that, 'In general, the "uniting” process has hardly begun, with significant cultural gaps remaining between the two groups' (Personal papers, Min. Initial Findings, 9, Informal Retreat, March 11-12, 2002). This was later confirmed by the Special Committee on Reformation (File UPCSA:GA, Report to General Assembly, 2003, UPCSA Papers for General Assembly:1999):

"The preparation for our union was poor; certainly not as deep or thorough as it could have been. But our uniting is proving to be the Lord's instrument to weigh and sift our idolatries. What do we, what will we, hold so dearly that it comes and stays between us and His will for the Church?”

However, it became clear that the financial crisis was itself a symptom of a deeper spiritual crisis in the denomination. Notwithstanding this, the first decision was to propose a vision 'To build an integrated,

3 This had the potential to become a serious impediment to union as some in the PCSA viewed the RPCSA support for union as a means of getting access to PCSA funds. The RPCSA made it clear they did not see the PCSA pension fund as a source of finance for themselves. 
relevant and thriving church in Southern Africa' with three strategic imperatives:

- Build a united denomination;

- Derive value for the Presbyterian franchise as a whole;

- Increase the incomes of the poorest congregations.

This body had neither power nor authority so it operated through the Finance Committee which presented its ideas and proposals to the 2002 General Assembly which agreed to appoint a Special Committee on Reformation to consider bringing proposals to the forthcoming Executive Commission and 2003 General Assembly " "to map out a plan for the reformation and possible restructuring of our denomination" and "to devise a plan that will facilitate a reformation of the spiritual life, work and mission of the UPCSA and facilitate the establishment of sound and effective managerial and financial structures”' (File UPCSA:GA, Min. 3.2, Progress Report from Special Committee on Reformation [SCR] to Executive Commission, 6 November 2002).

A critical issue that arose out of the work of the Skuilkloof Eleven was a comment that Zambia and Zimbabwe were a drain on the resources of the denomination. This caused a serious upset in the 2002 General Assembly and required sensitive handling to restore peace. However, this incident revealed how tenuous racial issues were and how much reconciliation had eluded the former PCSA. Arising out of a consultation held in Zimbabwe, it was reported: 'The reality and level of racial and gender discrimination and paternalism within the UPCSA: it is very serious and causes much pain. Again: relationships needing to be serviced adequately' (FILE UPCSA:GA, Report to General Assembly, 2003, UPCSA Papers for General Assembly:204).

\section{Special Committee on Reformation}

The context apart from that defined above was described as ignorance, prejudice and rumour-mongering that seems to find its way around the denomination far more efficiently than the "official" information required to make our system of governance work' (ibid.). Learning from the union process, it was decided to make good communication a priority. The first official communication threw down 
the gauntlet: 'Will we have the courage to change - reform?' (Personal papers, Botsis to All Ministers, Session Clerks and Presbytery Clerks, 15 January 2003). However, the communication problem was serious at the level of congregations because many did not submit financial and statistical returns which were necessary for budgeting and assessment purposes.

The Reformation Committee worked with the understanding of reformation as 'when something out of the kernel of the Gospel transforms the way we do things' (Personal papers, Min.6, Special Committee on Reformation [SCR], 19-20 May 2003). It later brought the challenge to the General Assembly:

“... will the UPCSA (...) have the courage to abandon what is not good and reform and keep on reforming so we become and remain a Church in Southern Africa which is a thing of beauty in God's hands: a body which lives with prophetic authority and has a loving and healing effect on the communities we serve" (File UPCSA:GA, Report to General Assembly, 2003, UPCSA Papers for General Assembly:199) [emphasis in original].

This was related to the important matter of relationships because this was crucial to any reform, renewal or reconciliation. The command to 'love one another' had to be given serious attention and practical expression. This was fundamental to the proposed Code of Conduct for Ministers:

I will seek to be Christlike in my attitude and behaviour toward all people of every gender, race, age, class or creed (7);

I will seek to share the gospel with people inside and outside the Church, with evangelistic zeal and with love and compassion (12);

I will proclaim Jesus Christ as Lord of life, uphold the ideal of a just and morally responsible society and do what I can to move people to work towards one (13);

I will strive to be reconciled to anyone who is estranged from me (18);

I will seek to promote racial harmony in my own congregation and the wider community (20) (File UPCSA:GA, Report to General Assembly, 2003, UPCSA Papers for General Assembly: 214-217). 
Issues which were considered by the Reformation Committee included the financial situation (which it was discovered was not as critical as the Skuilkloof Eleven had suggested, but which needed to focus on control of expenditure, assessments and giving), a Code of Conduct for Ministers (and renewal of ordination vows), denominational identity (congregational renewal of covenant, introduction of Reformation Sunday and celebration of the birthday of the denomination), Presbytery boundaries and organization, the restructuring and staffing of General Assembly Office, congregational integration, changes to probation for ministerial candidates, models of ministry and the transnational nature of the UPCSA. From this it became clear that spiritual, financial and structural issues were closely interlinked like cogs:

Seriously adjust one and the other two will turn as well. But to tamper with or reform any one means having to deal with the effects on the other 2 also File UPCSA:GA, Report to General Assembly, 2003, UPCSA Papers for General Assembly:199).

The issue of renewal was constantly before the committee. It took up the matter under five headings:

1 Personal renewal;

2 Corporate renewal;

3 Theological renewal;

4 Missiological renewal;

5 Structural renewal (Pool, Special Committee on Reformation, May 2003).

This became the remit of the Priorities and Resources Committee post2003.

In terms of structural renewal, it was noted that the PCSA had attempted this at various times unsuccessfully: 'The only really successful restructuring came during the Reformation of the $16^{\text {th }}$ and $17^{\text {th }}$ centuries' (Personal papers, Pool 2003). However, these past failures did not daunt the committee or the Executive Commission.

Linked to this are the Mission and Vision Statements of the UPCSA approved by the General Assembly in 2002: 


\section{Mission Statement}

The Mission of the Uniting Presbyterian Church in Southern Africa is to:

a. Bear witness to the saving gospel of Jesus Christ to all who do not now believe in Him;

b. Build up the believers in faith, hope and love through the ministry of the Holy Spirit;

c. Be faithful through our teaching And practice in proclaiming the sovereign rule of God in all social, economic, political and ecological relationships.

[Derived from this was a set of denominational priorities cf. Report of Priorities \& Resources, File UPCSA:GA, UPCSA General Assembly Papers, 2004:155-156].

Vision Statement

Our vision for the UPCSA is of a Church which is One:

in obedience to its Sovereign Lord

in celebrating its living heritage as a Reformed Church in Southern Africa

in celebrating its cultural diversity

in addressing injustices and poverty in church and society

in providing a model of racial reconciliation

From this it would seem that reconciliation was the culmination of the vision rather than its starting point. There was a declared need for vulnerable relationships to be formed, repentance, forgiveness, a reconciliation that is 'grounded in our love for Jesus' and greater than that 'of the world' (File UPCSA:GA, Report of Priorities \& Resources, UPCSA General Assembly Papers, 2004:155-156). As has been stated little has been done in this regard to date.

Yet, a prophetic word was offered to the General Assembly related to reconciliation:

"We believe that as a church we are being called to kneel before Christ and place into His hands our traditions and our agendas so 
that He may redeem them from idolatry and self will. We believe that we need to develop a new culture of habit and thought in which we express rather than suppress our joy in what God has given us in the Lord. In order to achieve this we need a 'change of our culture of habit and thought' and a desire to 'pursue the things that make for peace'” (File UPCSA:GA, Report of Priorities \& Resources, UPCSA General Assembly Papers, 2004:158).

\section{CONCLUSION}

What is clear is that it was secular and not theological understan-dings of reconciliation that have governed the process of reconcilia-tion in the Uniting Presbyterian Church in Southern Africa. This is a fundamental flaw. The process has focussed on the human perspec-tive and while much has been done prayerfully, the underlying unity in Christ has not been a primary focus. It took until the close of 2004 for it to be recognised that:

"When transformed we will be One and like Christ.

The essence of the Godhead is Unity and the gift of the Spirit to the Church is Unity! (Eph 4:3-6). The Unity is given: its maintenance and quality is dependent on our effort” (Personal papers, Botsis, Transformation beyond negotiation, paper delivered at Mission Imbizo, 26 November 2004, Benoni).

It will be difficult to achieve the reconciliation that is God's work without a recognition that:

"Reconciliation is central to the ministry of Jesus Christ. Whenever the Spirit of God settles on anything, it brings about healing, it brings about reconciliation, it brings about healing. Broken relationships are mended, broken marriages are put together again, broken characters are reconstituted anew. There is something wrong with a Church which is filled by the Holy Spirit, but which does not struggle with the issues which divide people” (Finca ibid.).

Then it will require tremendous commitment and stamina to see the project through. This is a divine imperative and we are required to exercise our ministry of reconciliation which is a continuation and extension of Jesus ministry on earth. 


\section{Consulted literature}

\section{Primary sources}

Minutes and papers of:

General Assemblies of Presbyterian Church of Southern Africa (PCSA), Reformed Presbyterian Church in Southern Africa (RPCSA) and Uniting Presbyterian Church in Southern Africa (UPCSA) (Files RPCSA:GA; PCSA:GA, UPCSA:GA);

Reformed Presbyterian Church in Southern Africa (RPCSA) and Presbyterian Church of Southern Africa (PCSA) Ecumenical Relations Committees (File SCU);

PCSA-RPCSA Union Talks Committees on Union (Union Negotiations Central Committee, UNCC) (File SCU);

Special Commission on Union (SCU) (File SCU);

(All these are held in the archive of the Uniting Presbyterian Church in Southern Africa, Joe Wing Centre, 150 Caroline Street, (PO Box 96188) BRIXTON, $2 \mathrm{O} 19$ (gensec@presbyterian.org.za).

The following (Personal papers) are also in the possession of the author

Basis of Union;

State of the Union;

Concerned Group (Amatola Presbytery) Statement;

Initial findings, Skuilkloof Retreat, 11-12 March 2002;

Minutes, Special Committee on Reformation (SCR), 19-10 May 2003;

Botsis R J Letter to Ministers, Session clerks and Presbytery Clerks, 15 January 2003;

Botsis, Transformation beyond negotiation, paper delivered at Mission Imbizo, 26 November 2004, Benoni; Finca BB. The vision and agenda of union: A church healed for the healing of a wounded nation, paper delivered at Mission Imbizo, 25 November 2004, Benoni;

Pool WD. Paper on Reformation, 2003.

\section{Secondary sources}

De Gruchy, 2002. Reconciliation: Restoring justice. London: SCM.

Duncan, G A 1997. Scottish Presbyterian church mission policy in South Africa, 1898-1923. Unpublished MTh dissertation. Pretoria: UNISA. 
-, 2003. Back to the future. Verbum et Ecclesia, 24(2), 359-373.

Hendricks, J 1999. A rainbow over the laager: The Dutch Reformed Church crossing the apartheid boiundary. Missionalia 27(3), 330-341.

Khabela, M G 2000. Race, ethnicity, ordination and titles (Unpublished paper, Propellor Conference, 26-29 June), Johannesburg.

Masango, M J 2000. Ministry: By whom, for whom, and how? (Unpublished paper, Propellor Conference, 26-29 June), Johannesburg.

Mpako, D 1999. Anti-racism work and reconciliation. Missionalia 27(2), 235-240.

Schreiter, R J 1992. Reconciliation: Mission and ministry in a changing social order. Maryknoll: Orbis

Volf, M 1996. Exclusion and embrace: A theological exploration of identity, otherness and reconciliation. Nashville: Abingdon.

Xapile, S P 1994. Unity negotiations between the Bantu Presbyterian Church and the Presbyterian Church of Southern Africa, 1959-1971 (Unpublished MA dissertation) Cape Town: University of Cape Town.

-, 1999. The quest for unity between the Bantu Presbyterian Church of South Africa and the Presbyterian Church of South Africa, 1959-1973 (Unpublished DTh thesis) Stellenbosch : University of Stellenbosch.

Zaru, J 2000. Taking inter-faith action. South African Outlook 2(2), 10. 